\title{
Penggunaan Perangkat Pembelajaran Geometri Ruang BERBASIS ICT UNTUK MENINGKATKAN KEMAMPUAN BERPIKIR TingKat Tinggi MaHASISWA
}

\section{THE USE OF ICT-BASED ON GEOMETRY SPACE LEARNING FOR IMPROVING STUDENTS' High LEVEl ORDER ThinKING ABILITY}

\author{
Desi Rahmatina \\ Pendidikan Matematika, Universitas Maritim Raja Ali Haji, Tanjungpinang \\ desirahmatina@gmail.com
}

\begin{abstract}
Abstrak
Pembelajaran geometri ruang merupakan salah satu pembelajran yang memerlukan kemampuan analitis dan komunikatif mahasiswa. Tujuan penelitian ini adalah 1) untuk mengkaji penggunaan perangkat pembelajaran geometri ruang berbasis ICT dalam meningkatkan kemampuan berpikir tingkat tinggi, 2) untuk mengetahui respon mahasiswa terhadap penggunaan perangkat pembelajaran geometri berbasis ICT. Pembelajaran geometri memerlukan kemampuan mengkomunikasikan bangun yang sifatnya abstrak menjadi konkrit sehingga dapat meningkatkan kemampuan berpikir tingkat tinggi dengan menggunakan ICT. Hasil kajian ini menunjukkan perangkat pembelajaran berbasis ICT dengan program wingeom dapat meningkatkan kemampuan berpikir tingkat tinggi.

Kata Kunci: ICT, program wingeom, berpikir tingkat tinggi.
\end{abstract}

\begin{abstract}
Learning geometry of space is one pembelajran that require analytical and communicative abilities of students. The purpose of this study were 1) to assess the use of the learning device geometry of space-based ICT in enhancing the ability to think critically, 2) to study the response of students to use ICT-based learning device geometry. Learning geometry requires the ability to communicate wake which is abstract into the concrete so as to increase high-level thinking skills by using ICT. Results from this study indicate the ICT-based learning with wingeom programs can increase high-level thinking skills.
\end{abstract}

Keyword: ICT, wingeom program, high level order thinking.

\section{Pendahuluan}

Information and Communication

Technologies (ICT) atau dikenal juga sebagai Teknologi Informasi dan Komunikasi (TIK). Perkembangan teknologi dalam kehidupan sehari hari yang semakin pesat mempunyai pengaruh terhadap

$$
\begin{aligned}
& \text { perkembangan teknologi dalam } \\
& \text { pendidikan terutama pendidikan } \\
& \text { matematika sebagaimana diungkapkan } \\
& \text { oleh Kristof DW and Nicky (2014) yang } \\
& \text { menyatakan bahwa" ICT infrastructure } \\
& \text { investments in educational institutions } \\
& \text { (i.e., primary schools, secondary schools, }
\end{aligned}
$$


colleges and universities) have been one of the key priorities of education policy during the last decade.

Manfaat penerapan ICT dalam pendidikan (UNESCO, 2013):

1. Mempermudah dan memperluas akses terhadap pendidikan

2. Meningkatkan kesetaraan pendidikan

3. Meningkatkan mutu pembelajaran

4. Meningkatkan profesionalisme guru

5. Meningkatkan efektifitas dan efisiensi manajemen, tata kelola dan admisnidtrasi pendidikan.

Perkuliahan geometri ruang merupakan pembelajaran aktif, kreatif,efektif dan menyenangkan jika diiringi dengan penggunaan perangkat pembelajaran yang menarik sehingga mahasiswa mampu mengeksplorasi konsep sehingga memicu kemampuan berpikir tingkat tinggi. Dalam mencapai kemampuan berpikir tingkat tinggi atau Higher Order Thinking (HOT), mahasiswa sudah memiliki terlebih dahulu kemampuan berpikir tingkat rendah atau lower order thinking seperti kemampuan mengingat,memahami dan mengaplikasikan. Menurut Tony Thomson (2008) mendefinisikan berpikir tingkat tinggi adalah the use of complex, non algorithmic thinking to solve a task in which there is not a predictable, wellrehearsed approach or pathway explicitly suggested by the task, task instruction, or a worked out example. Jadi, dapat disimpulkan bahwa berpikir tingkat tinggi mahasiswa dikategorikan sebagai tidak mengulang perkataan atau penjelasan dosen dan kemampuan mahasiswa menganalisis, mengevaluasi dan merancang.

Media atau perangkat pembelajaran merupakan unsur yang penting dalam pembelajaran geometri karena objek yang dikaji berupa benda abstrak, sehingga diperlukan perangkat yang dapat memudahkan mahasiswa memahami dan merancang atau mengkreasi objek abstrak menjadi konkrit.Penelitian tentang penggunaan ICT dalam pembelajaran geometri telah dilakukan oleh peneliti matematika seperti yang dilakukan oleh Royati,dkk (2010) membahas tentang pengaruh geogebra terhadap pencapaian matematika pada materi sistem koordinat pada geometri.

Dalam geometri ruang sangat diperlukan berpikir kritis dan analitis dan jika tidak diiringi dengan penggunaan metode dan media pembelajaran yang efektif maka siswa sukar memahami konsep materi geometri ruang.

Berdasarkan data Puspendik kemdikbud , persentase penguasaan materi geometri pada soal matematika Ujian Nasional 2014/2015 SMA (hasil UN responden) di provinsi Kepulauan Riau yaitu, kota Tanjungpinang, kota Batam, kabupaten Bintan,kabupaten Karimun, kabupaten Anambas,kabupaten Lingga ditampilkan dalam tabel 1. Penguasaan materi ujian tentang geometri ruang baik di tingkat kabupaten/kota maupun provinsi bahkan tingkat nasional dikategorikan rendah yaitu dibawah $50 \%$. 
Tabel 1.

Persentase penguasaan materi geometri ruang pada UN 2014/2015 di provinsi KEPRI

\begin{tabular}{ll}
\hline Kemampuan yang di uji & Menghitung jarak dan suatu titik \\
ke garis pada bangun ruang
\end{tabular}

Menentukan nilai perbandingan trigonometri sudut antara 2 bidang pd bangun ruang

\begin{tabular}{|llll|}
\hline Kab/Kota & Tanjungpinang & 12.89 & 23.76 \\
\cline { 2 - 4 } & Batam & 24.84 & 27.19 \\
\cline { 2 - 4 } & Bintan & 14.25 & 23.06 \\
\cline { 2 - 4 } & Karimun & 14.22 & 23.22 \\
\cline { 2 - 4 } & Natuna & 19.44 & 17.78 \\
\cline { 2 - 4 } & Lingga & 6.79 & 15.85 \\
\cline { 2 - 4 } & Anambas & 6.38 & 32.98 \\
\hline Propinsi & & 17.71 & 24.06 \\
\hline Nasional & & 35.08 & 40.07 \\
\hline
\end{tabular}

Sumber: Puspendik Kemendikbud

Berdasarkan tabel 1 di atas menunjukkan bahwa penguasaan siswa SMA tentang geometri ruang sangat lemah, siswa SMA di kota Batam memperoleh persentase lebih tinggi dari penguasaan materi geometri ruang tingkat propinsi, namun persentase penguasaannya lebih rendah dibandingkan tingkat nasional. Penguasaan materi tentang geometri pada UN 2014/2015 merupakan penguasaan terendah dibandingkan dengan materi lainnya seperti Aljabar, Trigonometri,Logika Matematika,statistika dan peluang serta Kalkulus seperti ditampilkan dalam SKL (Standar Kompetensi Lulusan ) UN 2014/2015 (Puspendik Kemdikbud). Penggunaan media/perangkat pembelajaran geometri berbasis ICT diperlukan karena mempunyai kelebihan, diantaranya 1)Memberikan perubahan objek berulang dan dinamis, 2)Menampilkan desain menarik, 3) Menampilkan animasi gambar dan suara, 4) menimbulkan berpikir kritis dan kreatif dalam mengeksplorasi objek objek geometri.

Rumusan masalah dalam kajian ini adalah "bagaimana menggunakan perangkat pembelajaran geometri ruang berbasis ICT sehingga dapat meningkatkan berpikir tingkat tinggi mahasiswa." Adapun tujuan kajian ini adalah untuk mendeskripsikan penggunaan perangkat pembelajaran geometri ruang berbasis ICT dalam meningkatkan kemampuan berpikir tingkat tinggi mahasiswa.

\section{Metode}

Metode kajian yang digunakan dalam penelitian ini adalah merupakan jenis penelitian pengembangan (developmental research) dalam bentuk design research. Menurut Borg and Gall (2003: 569), Educational Research and Development (Educational $R \& D$ ) is an industry-based development model in which the findings of the research are used to design new products and procedures, which then are systematically field-tested, evaluated, and refined until they meet specified criteria of effectiveness, quality, or similar standard." 


\section{Atau dapat diartikan bahwa "model} berbasis pengembangan merupakan temuan penelitian yang digunakan untuk merancang produk dan prosedur baru, yang kemudian secara sistematis diuji di lapangan, dievaluasi, dan disempurnakan sampai memenuhi kriteria efektivitas, kualitas, atau standar yang sama."

Menurut Santyasa (2009 : 3), penelitian pengembangan dalam rangka peningkatan kualitas pembelajaran memiliki karakteristik sebagai berikut.

1. Masalah yang ingin dipecahkan adalah masalah nyata yang berkaitan dengan upaya inovatif atau penerapan teknologi dalam pembelajaran sebagai pertanggung jawaban profesional dan komitmennya terhadap pemerolehan kualitas pembelajaran.

2. Pengembangan model, pendekatan dan metode pembelajaran serta media belajar yang menunjang keefektifan pencapaian kompetensi siswa.

3. Proses pengembangan produk, validasi yang dilakukan melalui uji ahli, dan uji coba lapangan secara terbatas perlu dilakukan sehingga produk yang dihasilkan bermanfaat untuk peningkatan kualitas pembelajaran. Proses pengembangan, validasi, dan uji coba lapangan tersebut seyogyanya dideskripsikan secara jelas, sehingga dapat dipertanggung jawabkan secara akademik

4. Proses pengembangan model, pendekatan, modul, metode, dan media pembelajaran perlu didokumentasikan secara rapi dan dilaporakan secara sistematis sesuai dengan kaidah penelitian yang mencerminkan originalitas.

Tahapan dalam penelitian ini adalah ditampilkan dalam gambar 1

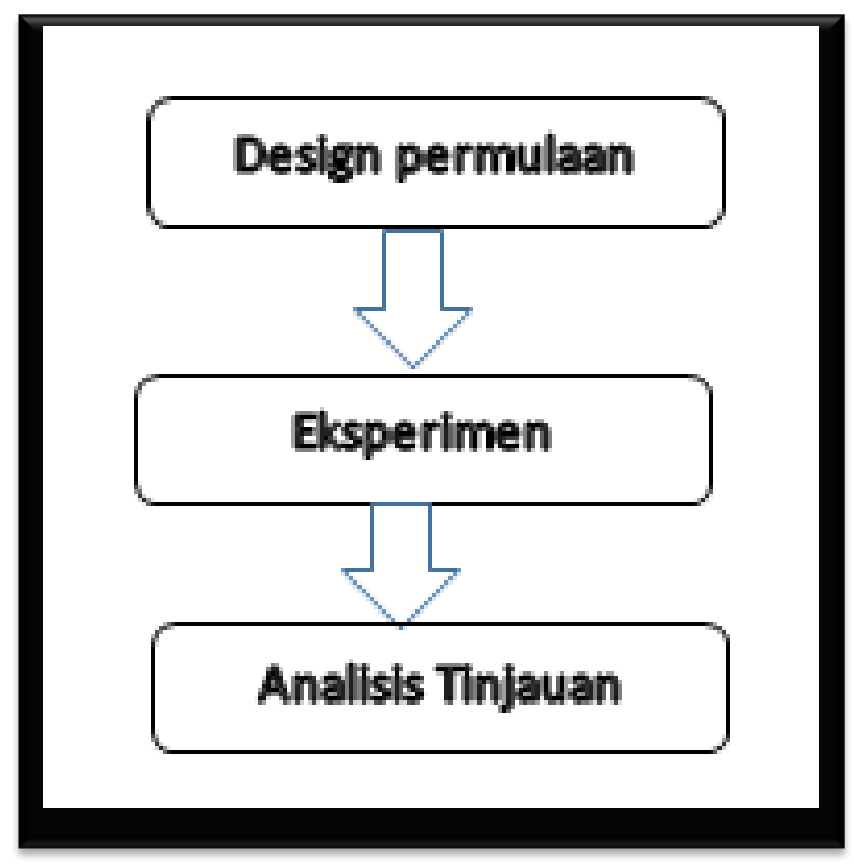

Gambar 1. Tahapan Penelitian. 
Pada tahap design permulaan, dibuat lintasan belajar(proses berfikir) tentang hal yang terjadi pada mahasiswa tentang pemahaman konsep geometri ruang. Pada tahap eksperimen, media atau perangkat pembelajaran ICT diuji cobakan sebagai alternatif pemecahan masalah. Pada tahap Analisis Tinjauan, data pada hasil eksperimen dianalisis untuk mendapatkan kesimpulan serta kemungkinan langkah yang akan dilakukan untuk meningkatkan pemahaman tentang konsep geometri.

Sampel dalam kajian ini adalah mahasiswa semester 4 tahun akademik 2015/2016 di prodi pendidikan matematika Fakultas Keguruan dan IImu Pendidikan Universitas Maritim Raja Ali Haji.

Data yang digunakan dalam penelitian ini berupa:

\section{Angket/kuesioner/wawancara} berupa pertanyaan mengacu kepada pengalaman atau kegiatan yang dilakukan selama pembelajaran geometri.

2. Observasi/pengamatan langsung yang dilakukan untuk mengamati kegiatan pembelajaran geometri.

\section{Hasil dan Pembahasan}

Memuat hasil dan pembahasan tentang penelitian yang dilakukan. Bagian ini merupakan bagian utama artikel hasil penelitian dan biasanya merupakan bagian terpanjang dari suatu artikel. Hasil penelitian yang disajikan dalam bagian ini adalah hasil "bersih". Penulis tidak perlu menyajikan proses analisis data seperti perhitungan statistik dan proses pengujian hipotesis. Hanya hasil analisis dan hasil pengujian hipotesis saja yang perlu dilaporkan. Tabel dan grafik dapat digunakan untuk memperjelas penyajian hasil penelitian secara verbal. Tabel dan grafik harus diberi komentar atau dibahas.

Pada design permulaan, peneliti mendapat informasi tentang hal yang terjadi pada mahasiswa mengenai konsep geometri, berdasarkan instrumen yang diberikan kepada mahasiswa berupa angket tentang penggunaan perangkat /media pembelajaran geometri ruang (kubus dan balok) diperoleh narasi yang ditulis oleh mahasiswa sebagai calon guru tentang pengalaman mereka selama belajar di sekolah tentang geometri, bahwa guru hanya mengajar secara konvensional, menulis di whiteboard yang hanya menggunakan spidol dan terkadang menggunakan kertas karton untuk membuat objek geometri seperti jaring jaring kubus dan balok. Berdasarkan pengalaman mereka juga tentang penggunaan program/software dalam pembelajaran geometri, ternyata semua mahasiswa menyatakan bahwa selama di sekolah mereka belum pernah diperkenalkan penggunaan ICT atau menggunakan program/software dalam pembelajaran matematika, khususnya pembelajaran geometri. Disamping itu, mahasiswa juga berpendapat bahwa ketika duduk di bangku sekolah, pada saat mempelajari geometri, guru menggunakan metode ceramah dan tidak pernah menggunakan alat peraga dan media 
pembelajaran yang menarik. Berdasarkan pernyataan di atas terungkap bahwasanya proses pembelajaran geometri di sekolah masih secara tradisional dan belum adanya penggunaan ICT dalam pembelajaran geometri atau belum diterapkan penggunaan software/program di sekolah dalam rangka peningkatan minat dan kemampuan berpikir tingkat tinggi dalam proses pembelajaran geometri terutama pada materi bangun ruang.

Pada tahap eksperimen, peneliti menggunakan media pembelajaran berbasis ICT (penggunaan software pembelajaran wingeom) sebagai solusi pemecahan masalah geometri yang dialami mahasiswa, sebagaimana Yaya S. Kusumah (2003) mengemukakan bahwa inovasi pembelajaran dengan bantuan komputer sangat baik untuk diintegrasikan dalam pembelajaran matematika terutama geometri. Disamping itu penggunaan teknologi informasi dalam pendidikan matematika juga menjadi perhatian NCTM (2000) sehingga ditetapkannya 6 standar dalam pembelajaran matematika yaitu, 1) Equity, 2) Curriculum., 3) Teaching, 4) Learning, 5) Assessment dan 6)Technology.

Penggunaan perangkat pembelajaran dengan program wingeom dalam rangka usaha untuk meningkatkan kemampuan berpikir tingkat tinggi mahasiswa melalui kegiatan/aktivitas-aktivitas yang didiskusikan secara berkelompok sehingga mahasiswa bebas merancang sendiri konsep geometri ruang untuk pengembangkan proses berpikir mahasiswa, pembelajaran berpusat kepada mahasiswa sehingga mahasiswa berkesempatan untuk mengeksplorasi konsep konsep geometri ruang.

\section{AKTIVITAS 1}

Tujuan: Membuat jaring jaring kubus dan balok

Dalam aktivitas I ini mahasiswa diberi kebebasan mengeksplorasikan dan mendemonstrasikan kemampuan berpikir mereka untuk merancang berbagai bentuk jaring jaring kubus dengan menggunakan wingeom sehingga dapat meningkatkan kemampuan berpikir kritis dan berpikir level tinggi.

Langkah kerja:

1. Buka program wingeom

2. Klik window $\rightarrow 3$ dim

3. Klik Unit $\rightarrow$ Polyhedral $\rightarrow$ Box

4. Isi submenu rectangular box yang menyatakan panjang panjang rusuk yang diinginkan, jika bangun yang dibuat kubus, maka rectangular box tersebut diisi sama besar pada length, width dan height, jika yang dibentuk bangun ruang balok, maka salah satu ukuran length, width dan height .

5. Gambar kubus dan balok digerakkan dengan menggunakan tombol anak panah atas dan bawah kiri, dan jika ingin memperbesar gambar tekan tombol Page Up dan memperkecil gambar dengan menekan tombol Page Down.

6. Klik menu Anim $\rightarrow$ \#slider, gerakkan slider ke kanan dan kekiri 


\section{Klik reverse atau cyclic}

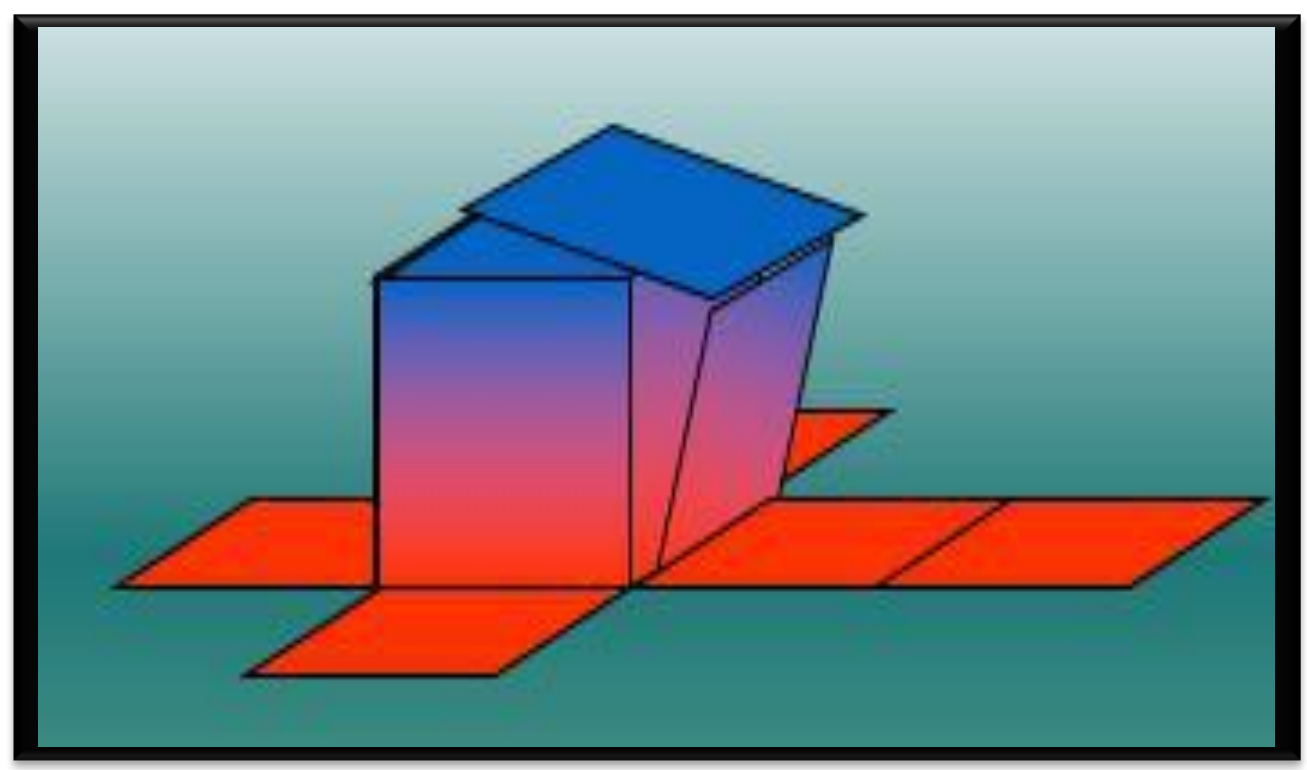

Gambar 2. Jaring jaring kubus menggunakan wingeom.

\section{AKTIVITAS 2}

Tujuan: Menentukan luas dan volume kubus dan balok

Dalam aktivitas II ini mahasiswa diberi kebebasan berpikir untuk menentukan luas dan volume kubus dan balok menggunakan wingeom sehingga dapat meningkatkan kemampuan berpikir mahasiswa.

Langkah kerja:

Menghitung luas dan volume kubus

1. Buka gambar kubus pada aktivitas I

2. Klik meas, ketik $A B$ kemudian enter, ketik $6^{*} A B$ lalu enter

3. Klik meas, ketik $A B^{*} A B^{*} A B$ lalu enter untuk menghitung volume kubus atau klik other $\rightarrow$ volume
Menghitung luas dan volume balok

1. Buka gambar balok pada aktivitas I

2. Klik meas, isi kotak measurements, ketik(

$2 *(A B * B C)+2 *(A B * B F)+2 *(B C * B F))$

untuk menghitung luas balok

3. Klik meas, isi kotak measurements, ketik $A B^{*} B C^{*} C G$ atau klik other/volume lalu edit nama balok yang akan dihitung volumenya, lalu klik ok. Sehingga muncul nilai volume balok.

Sebagian hasil dari kerja mahasiswa pada aktivitas 1 dan aktivitas 2 ditampilkan pada gambar 3 dan gambar 4 . 


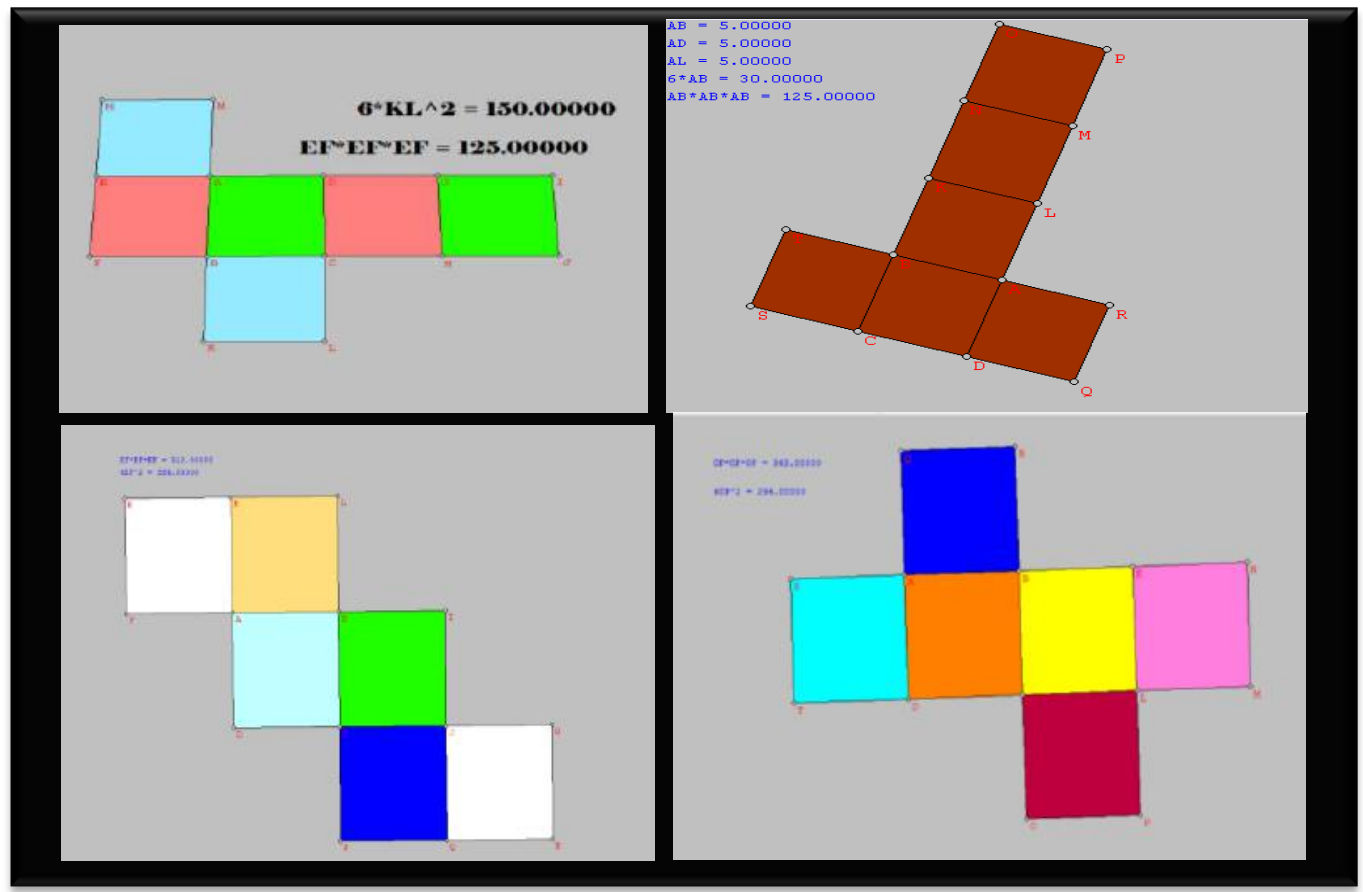

Gambar 3. Jaring jaring luas dan volume kubus.

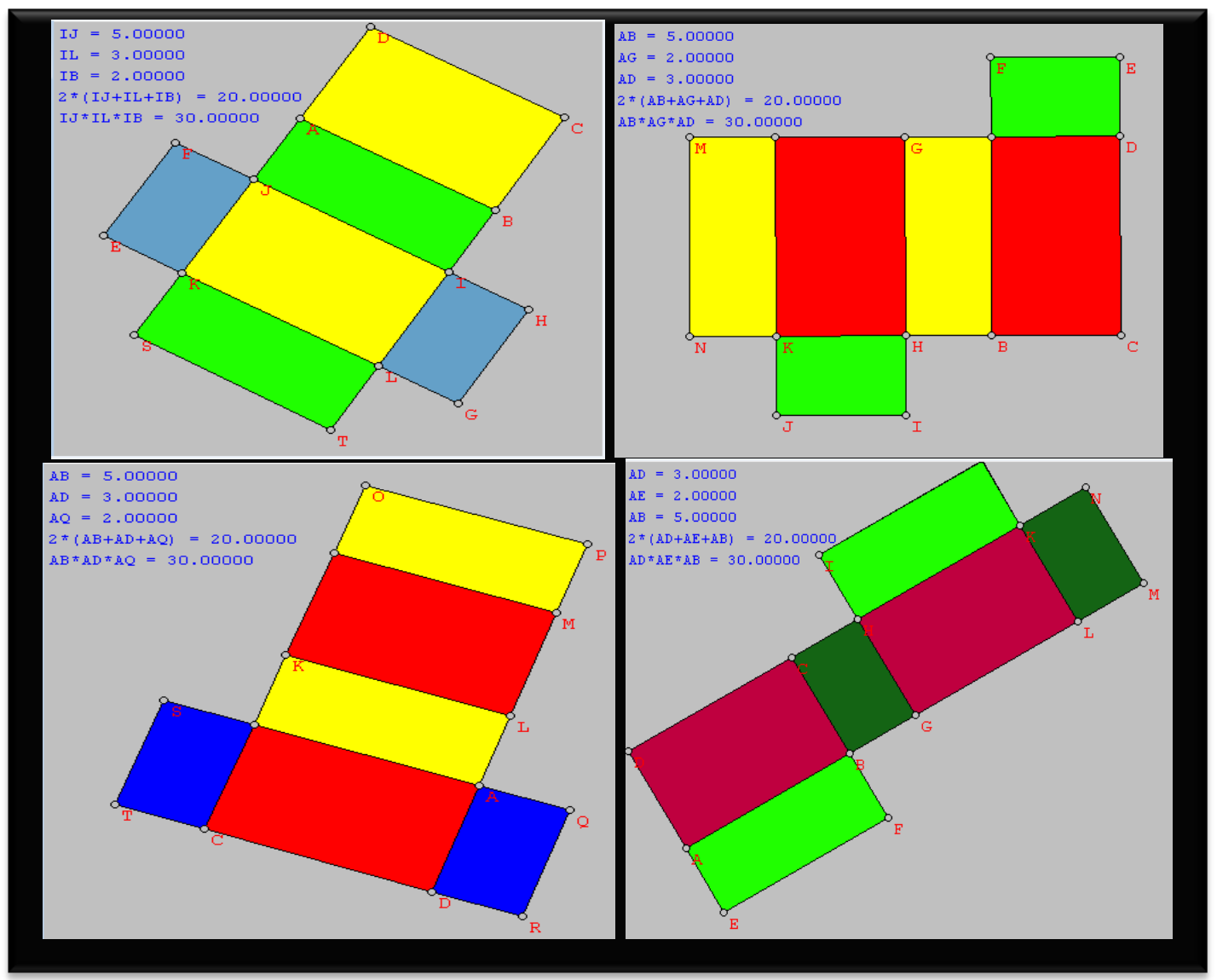

Gambar 4. Jaring jaring luas dan volume balok. 
Berdasarkan gambar 3 dan gambar 4 di atas, memberikan informasi bahwa mahasiswa dapat mendemonstrasikan, merancang serta dapat menghasilkan berbagai alternatif bentuk jaring jaring kubus dan balok serta menghitung luas dan volumenya dengan efektif menggunakan program wingeom sehingga dapat meningkatkan kemampuan berpikir tingkat tinggi mahasiswa, hal ini sejalan dengan yang diungkapkan oleh Yee Mei Heong,dkk (2012) bahwa Learning HOTS will also enhance an individual's mind; leading to the production of a variety of alternatives, ideas, actions, solutions and design. Therefore, students should learn and use HOTS to generate ideas so they can complete their assignments more effectively."( Pembelajaran dengan HOT akan meningkatkan kemampuan individu, mengarahkan untuk dapat menghasilkan berbagai alternatif, ide, pendapat, solusi dan desain. Oleh sebab itu siswa harus belajar menggunakan HOT untuk menghasilkan ide sehingga mereka dapat menyelesaikan tugas mereka dengan lebih efektif). Dan kemampuan merancang atau berkreasi yang dimiliki mahasiswa juga sesuai dengan kata kerja pada HOT sebagaimana diungkapkan Rahmatina,D (2015) bahwasanya kata kerja yang dapat digunakan dalam membentuk berpikir tingkat tinggi diantaranya: 1) Kemampuan menganalisis terdiri dari kata menguji, membagankan, menemukan, mengaitkan dan mengukur, 2) Kemampuan mengevaluasi terdiri dari kata membandingkan, membuat hipotesis, memprediksikan, membuat keputusan dan membuktikan 3) kemampuan mengkreasi terdiri dari kata mengkombinasikan, membentuk, merancang, mengatur, dan menyusun.

Setelah penggunaan program wingeom ini dilaksanakan, mahasiswa diminta untuk mengekspresikan pendapatnya tentang penggunaan software pembelajaran yang selama ini ternyata mereka belum pernah mempelajarinya dibangku sekolah. Adapun hasil pandangan mahasiswa diantaranya software wingeom merupakan program yang bagus dan dapat membantu langsung berhadapan bagaimana bentuk bangun ruang yang ingin dicari dan dapat menvisualisasikan objek kubus dan balok.

Tahap analisis Ianjutan pada penelitian ini ditemukan bahwa perlu adanya penerapam ICT dalam pembelajaran geometri ruang seiring dengan perkembangan teknologi informasi saat ini, sehingga siswa/mahasiswa dapat mengungkapkan kemampuan berpikirnya dengan merancang berbagai ide sehingga dapat menvisualisasikan objek geometri.

\section{Penutup}

Penelitian ini mengkaji penggunaan ICT dalam pembelajaran geometri ruang untuk meningkakan kemampuan berpikir tingkat tinggi mahasiswa. Dalam merancang berbagai bentuk objek (jaring jaring kubus dan balok) menggunakan program wingeom juga memerlukan skill dan kemampuan mengatur waktu sehingga 
dapat menyelesaiakan tugas yang diberikan dengan tepat.

Disarankan bahwa penggunaan ICT ini juga dapat diperkenalkan kepada siswa di sekolah sehingga siswa mempunyai kemampuan menggunakan teknologi dalam pembelajaran geometri dan dapat melatih berpikir kritis dan HOT.

\section{Daftar Pustaka}

Anderson, L W dan Krathwohl D.R., et al (2001). A Taxonomy for Learning, Teaching and Assessing: A Revision of Bloom"s Taxonomy of Educational Objectives. Allyn \& Bacon. Boston,MA (Pearson Educational Group).

Bloom, B., Madaus, G., \& Hastings, J.,(1981). Evaluation to improve learning. McGraw-Hill:

New York, NY.

Borg \& Gall (2003). Education Research. New York : Allyn and Bacon.

Rahmatina,Desi (2015). Kemampuan Berpikir Tingkat Tinggi Siswa Pada Pokok Bahasan Statistika Kelas VIII. Jurnal KIPRAH FKIP UMRAH. Vol 6 No.6.

Kristof De Witte dan Nicky (2014). Does ICT matter for effectiveness and efficiency in mathematics education?. Computers \&Education 75 (2014), 173-184. Elsevier Ltd.

NCTM,2000. Principles and Standars for

School Mathematics. Association Drive, Reston, VA 20191- 9988

Puspendik Kemdikbud. Laporan Hasil Ujian Nasional 2014.
Royati A.S, Ahmad Fauzi M dan Rohani A.T (2010). The Effects of GeoGebra on Mathematics

Achievement:Enlightening

Coordinate Geometry Learning.

Procedia Social and Behavioral

Sciences 8.pp 686-693.

Santyasa, (2009). Metode Penelitian Pengembangan dan Teori

Pengembangan Modul.

Sugiyono,(2008).Metode Penelitian Kuntitatif Kualitatifdan R\&D. Bandung. Alfabeta

Thompson,Tony, (2008). Mathematics Teachers" Interpretation of Higher Order Thinking In Bloom Taxonomy, International Electronic Journal of Mathematics Education (IEJME) Volume 3, Number 2. ISSN. 13063030.

UNESCO (2013), Paris, France.

Yaya S. Kusumah. (2003). Desain dan Pengembangan Bahan Ajar Matematika Interaktif Berbasiskan Teknologi Komputer. Proceeding National Seminar on Science and Mathematics Education. Seminar diselenggarakan oleh Fakultas Matematika dan Ilmu Pengetahuan Alam UPI bekerja sama dengan JICA.

Yee Mei Heong, Jailani Md Yunos, Widad Othman, Razali Hassan, Tee Tze Kiong dan Mimi Mohaffyza Mohamad (2012). The needs analysis of learning higher order thinking skills for generating ideas. Social and Behavioral Sciences 59. Pp $197-203$ 
Vidakovic, D., Bevis, J., \& Alexander, M. (2003). Bloom's Taxonomy in developing asessment items. Journal of Online Mathematics and its Applications. 
This page is intentionally left blank 